Workers, Families, and Immigration Policies

\author{
Leisy J. Abrego \\ University of California, Los Angeles \\ abrego@ucla.edu \\ Shannon Gleeson \\ Cornell University \\ smg338@cornell.edu
}

T. Payan, E. de la Garza (eds.), Undecided Nation, Immigrants and Minorities, Politics and Policy 6. 
Unauthorized Immigration in the US

Unauthorized immigration to the US has a long and varied history shaped by a number of shifts in immigration policy. Of the global immigrant stock, $10-15 \%$ is estimated to be undocumented (20-30 million; International Organization for Migration 2008). Today, undocumented immigrants comprise roughly $40 \%$ of the immigrant flow to the US. Although immigrants often come to this country as a result of complex factors that were initiated or supported by the US-including free trade agreements and wars that devastated immigrants' home countries and their national economies-once they become unauthorized, they find themselves in extremely vulnerable positions. Besides being low-wage workers targeted for exploitation, immigrants are also parents raising families and trying to get a foothold in US society.

The last few decades in policy changes and enforcement tactics have been especially harsh toward unauthorized immigrants, as they have led to changes in migration and settlement patterns that make more people vulnerable over longer periods of time. The militarization of the US southern border with Mexico has increased the dangers of crossing so much that the previous seasonal migration of mostly male migrants was slowed down to a trickle. While the economic recession that began in 2007 has slowed the flow of migrants, other factors such as border security have also certainly played a role in the magnitude and method of migration (Wasem 2012). Rather than risk their lives at each crossing, many undocumented immigrants have opted to remain in the US and settle. For those with families, bringing their relatives to settle along with them was the only way to guarantee family unity. This drastic shift in migration patterns has led to previously unseen numbers of unauthorized women and children who must also navigate the consequences of immigration policies in their family life (Hondagneu-Sotelo 
1994). The recent surge of undocumented children crossing from Central America has highlighted the urgency of this crisis.

Public debates on immigration, however, have until recently focused exclusively on male adult migrants. As the scholarly literature shifts to examine the patterns and experiences of immigrant families, this chapter reviews the complex and multifaceted consequences of immigration policies for these families. Notably, both the long stalemate of immigration reform at the federal level and the fast pace of policy changes at the state and local levels have had deep repercussions for immigrant families who must navigate policies in a context that heavily restricts their paths to legalization.

Immigration Enforcement and the Labor Market

Today, new technologies facilitate limitless communication and travel, while integrated markets create global economies. Yet, behind the veneer of seamless economic and cultural integration are millions of undocumented workers who labor in the shadows. While some temporary visas are available for low-skilled migrants, their availability pales in comparison to the size of the unauthorized migrant flow. Though opportunities also exist for family reunification, the wait time can be up to 10-20 years for those immigrants whose countries of origin produce the largest unauthorized migrant populations.

Therefore, the demand for cheap labor in the US, coupled with a lack of employment opportunities in the country of origin, has fueled much of the unauthorized migration we currently observe. The vast majority of these migrants have become integral to local labor forces. The US is home to an estimated 8 million of these unauthorized workers, who make up $5.2 \%$ of the US labor force, and come primarily from Mexico and Latin America (Passel and Cohn 2009; Passel and Cohn 2011). 
The majority of undocumented immigrants in the US are men of prime working ages; lower proportions of unauthorized are children or elderly. Yet, these figures are deceiving, given that undocumented status is a fluid state. For example, more than 300,000 immigrants currently live in the US under Temporary Protected Status (TPS) - a deferred action that grants temporary relief from deportation and a work permit to immigrants from recognized countries that have undergone a natural disaster or conflict (Hoefer et al. 2011; Simmelink 2011). TPS typically spans a period of 18 months, and its renewal is left to the whims of Congress. Consequently, these immigrants frequently slip in out of legal status depending on the political landscape. This uncertainty can also facilitate labor exploitation and block social mobility, with particular detriment to women and workers in the informal economy (Salcido and Menjívar 2012).

In addition to being overrepresented in low-wage industries, undocumented workers are among the most vulnerable to workplace violations such as wage theft, sexual harassment, and occupational injury. Of the day labor workforce, $75 \%$, for example, is undocumented. In a recent survey, half of day laborers reported being denied payment altogether; a third had worked more hours than agreed to with their employer; and more than a quarter had been abandoned at a worksite (Valenzuela et al. 2006). Similar findings have emerged in other high immigrant industries such as domestic work, where a study by the National Domestic Workers Alliance found that " $85 \%$ of undocumented immigrants who encountered problems with their working conditions in the prior 12 months did not complain because they feared their immigration status would be used against them" (Burnham and Theodore 2012, p. xii). They also reported lower wages, more severe financial hardships, more problematic working conditions, and higher injury rates (20).

Findings from the 2008 Unregulated Work Survey (based in three of the largest immigrant destinations of Los Angeles and New York) confirm that undocumented workers overall are more likely 
to have even the most basic of workplace protections violated (Bernhardt et al. 2009). The authors found that 47.4 and $29.5 \%$ of foreign-born unauthorized women and men, respectively, reported minimum wage violations. In comparison, 24.2 and $13.5 \%$ of foreign-born authorized, and 16.1 and 14.9 $\%$ of US-born women and men reported the same (Bernhardt et al. 2009). In sum, finding work, dealing with exploitation, and securing fair wages are central matters for immigrants and their families.

Indeed, across industries, undocumented workers are disproportionately employed in riskier occupations and industries and suffer a disproportionate share of worker fatalities (Loh and Richardson 2004). The Department of Labor reports that the top wage and hour violators are concentrated in lowwage sectors commonly populated by undocumented immigrants, such as agriculture, restaurants, garment manufacturing, and janitorial services (Department of Labor 2007). Furthermore, a recent report by the AFL-CIO highlights the common practice of employers threatening to call immigration authorities if workers pursue claims (Avendaño and Hincapié 2008, citing Morgan et al. 2006). Unsurprisingly, a number of other studies have found similar patterns of exploitation (e.g., Foo 1994; Gordon 2007; Nissen et al. 2008).

The situation for undocumented workers and their families is especially complex given what Griffith (2012) has dubbed, "immployment law." On one hand, undocumented immigrants are not permitted to legally reside or work, yet most of them find employers ready and willing to hire them. Under the Immigration Reform and Control Act (IRCA) of 1986, which instituted employer sanctions that penalize employers who hire undocumented workers, all employers are required to submit documents to establish the identity and work authorization status of new employees. More generally, a complex set of federal and state laws working at cross-purposes creates a confusing and contradictory context for undocumented immigrants and their families. The last two decades in particular have given way to a considerable number of challenges for undocumented workers. The 2002 Supreme Court ruling in 
Hoffman Plastic Compounds, Inc. v. NLRB, was especially harmful, precluding undocumented workers from receiving key remedies of job reinstatement and back pay within the context of the National Labor Relations Act.

Even though undocumented workers are subject to deportation, they nonetheless are eligible for a limited array of labor protections at both the federal and state level (e.g., the National Labor Relations Act-NLRA 1935, the Federal Labor Standards Act-FLSA 1938, Title VII of the 1964 Civil Rights Act, and the Occupational Health and Safety Act 1970). In 2008, the Supreme Court denied certiorari in Agri Processors, Inc. v. National Labor Relations Board, letting the lower court ruling stand and reasserting an undocumented worker's eligibility to participate in union elections. Although this decision affirmed the premise that undocumented immigrants have access to basic workers' rights (Motomura 2010), other actions, such as the 2011 National Labor Relations Board ruling in Mezonos Maven Bakery, Inc., have been more restrictive. In Mezonos, the board concluded that undocumented workers were ineligible for back pay remedies even in cases where the offending employer knew about their unauthorized status when they hired them (NLRB 2011). The current environment of "rights without remedies" has created a culture of fear among undocumented workers, furthered their exploitation, and stifled collective bargaining efforts (Berman 2004; Calderon-Barrera 2003; Fisk et al. 2005; NELP and MALDEF 2003; Walsh 2003; Wishnie 2007). It has also permitted major disparities to continue beyond the arena of union organizing.

Memoranda of understanding between federal immigration and labor standards enforcement authorities have attempted to address the interference of immigration enforcement on worker rights. A series of agreements mitigate the sharing of information between agencies, and provide for prosecutorial discretion in cases involving labor rights disputes. However, several Immigration and Customs Enforcement (ICE) operations, such as those that ensnared hundreds of workers at a poultry 
plant in Postville, IA and another at a transformer factory in Laurel, MS in 2008, have indeed disrupted ongoing labor organizing campaigns and labor violation investigations. In each of these cases, immigrant families bore the brunt of the short- and long-term consequences of such enforcement tactics (Thronson 2008).

Though worksite raids have officially slowed under the Obama Administration, other controversial "interior enforcement" tools such as the "Social Security No-Match letters" (which alert employers to the presence of a worker whose Social Security Number cannot be verified) and the "EVerify" program (an Internet-based employee eligibility verification system that is currently mandatory for any federal contractor) have contributed to worker exploitation. Critics argue that both programs grant employers considerable power to engage in union busting and deter workers from speaking up about workplace violations. In all of these cases, policies block the ability for immigrant workers to fulfill their responsibilities and goals as parents and family members is made more difficult.

This is not to say that undocumented workers do not speak up. However, those who do are more likely to encounter employer intimidation. To examine this process of claims-making, we draw on an original survey of 453 claimants seeking assistance from one of four workers' rights clinics in the San Francisco Bay Area that served a large immigrant population (Gleeson 2013). The findings revealed that structural challenges make it difficult for workers to access workplace rights on their own due to: (1) disjointed bureaucracies that have few institutional incentives to coordinate their efforts, (2) a system of employer penalties that incentivizes litigation and does not effectively address repeat employer offenders, and (3) statutes that leave vast numbers of workers without protection.

The aforementioned survey queried foreign-born respondents about the climate of fear at their workplace. Almost no claimants ( $3 \%$ of both foreign-born and undocumented workers) contended with employers who threatened to call immigration authorities. A similarly negligible level reported ever 
experiencing a raid at their workplace. However, $37 \%$ of those surveyed were undocumented. Of these workers, $90 \%$, as well as $80 \%$ of documented respondents, agreed that “workers who don't have papers are more targeted for workplace abuse."

During this research, we also spoke with a sample of injured undocumented workers in agriculture, an industry where at least half of workers are estimated to be undocumented. Many of these workers are seasonal and subcontracted employees. Undocumented status amplified these and other detrimental workplace dynamics such as at-will employment, lack of union representation, access to health insurance, and job security. Legal status certainly shapes workers' access to the job market, their willingness to speak out against workplace violations, workers' capacity to navigate the claims bureaucracy, and ultimately the inability to access benefits afforded to disabled workers who are no longer able to return to work (Gleeson 2010). Each dynamic in turn determines opportunities for wellbeing and mobility of immigrant families relying on the wages and consistent employment of undocumented workers.

The Economic Precarity of Undocumented Workers and Their Families

In addition to the $5.2 \%$ of US workers who are undocumented, there are a substantial number of undocumented children in the US, and undocumented workers are often embedded in mixed-status families. The number of unauthorized children has declined from a peak of 1.6 million in 2003 to about 1 million in 2010 (Passel and Cohn 2011). Of the unauthorized immigrants, $13 \%$ are children (as against 27 $\%$ of US-born and $6 \%$ of legal immigrants). However, according to 2010 estimates, close to threequarters of the 5.5 million children of unauthorized immigrants ( $73 \%)$ were born in the US. Nearly half (48\%) of unauthorized immigrants live with their children, and this is true particularly for women. All of 
this signals the large proportion of "mixed status" families (i.e., families with immigrants in various legal statuses; Passel and Cohn 2009; Passel and Cohn 2012) that rely on the wages and consistent employment of undocumented workers.

The consequences of the various legal decisions and enforcement practices against undocumented workers we detailed earlier in this report are present in the lives, and directly influence the well-being, of families. Undocumented workers earn far less than their native-born counterparts (a median household income of US\$ 36,000 vs. US\$ 50,000) and do not experience the same income mobility over time, as do other immigrants (Passel 2009). As a result, a third of the children of unauthorized immigrants live in poverty, nearly double the rates for those with US-born parents (18\%; Passel 2009). While long-time legal immigrants are just as likely as US-born individuals to be homeowners, the same is not true of long-term unauthorized immigrants, which consequently impacts housing stability and wealth accumulation opportunities for immigrant families. Unauthorized immigrants are also at a high risk of being uninsured, with nearly $60 \%$ lacking health insurance in 2007 (nearly twice the proportion of legal immigrants and four times the proportion of US-born adults). While the children of unauthorized immigrants fare better than their parents, they are still significantly disadvantaged compared with their US-born and legal resident counterparts (Passel 2009).

Unauthorized parents are working to raise and support children in what has been an increasingly harsh political and legal context that powerfully impacts their prospects for economic and emotional well-being. Immigration laws passed in the 1990s - particularly, the Illegal Immigration Reform and Immigrant Responsibility Act and the Personal Responsibility and Work Opportunity Reconciliation Act (both passed in 1996)-have drastically reduced immigrants' access to social benefits while blocking paths to legalization and expanding the grounds for deportation of documented and undocumented immigrants (Menjívar and Abrego 2012). Moreover, after the attacks of September 11, 
2001, new agreements between the Immigration Customs Enforcement (ICE) agency and local law enforcement spread across the country, facilitating a dramatic increase in racial profiling, while also weakening mechanisms that previously helped maintain community security.

Under these circumstances, immigrants and their families face steep hurdles in their attempts to become upwardly mobile. Here, it is worth underscoring the often overlooked point in policy discussions that immigration laws do not only affect unauthorized immigrants. For example, economic precarity resulting from limited job opportunities and rampant employer intimidation of unauthorized workers, in turn, has multiple and profound consequences for workers' entire families. Not unlike other members of the working poor, therefore, families that rely on the limited income of unauthorized workers can usually only afford to live in areas of dense poverty (Chavez 1998). Low-performing schools, high rates of crime, and few recreational activities are common in these communities, blocking immigrants' paths to positive integration over the long term (Abrego and Gonzales 2010).

Unlike other working poor people, however, undocumented immigrants and their families have few institutionalized resources to help them overcome the challenges of poverty. For example, while undocumented workers are generally eligible for workers' compensation benefits, they are ineligible to access long-term welfare state benefits such as unemployment and federal social security disability payments. Similarly, while unauthorized children are legally permitted to attend public school in grades $\mathrm{K}-12$, different states have various policies that can prohibit or make college too expensive to access, thereby also blocking the student's (and his or her family's) ability to thrive.

One of the more damaging effects of US immigration policies in immigrant parents' lives is how fear of deportation shapes their decisions not to access resources that would benefit their families. After an ICE raid in their community, for example, parents are likely to keep children home from school and generally avoid interacting with anyone who represents a public agency. The fear of deportation also 
keeps these immigrant parents from dealing with public health workers who may disclose their status to immigration authorities. In this way, parents risk their own health and, potentially, that of their children, even when the latter are US citizens who legally have access to these very resources. The lack of access to social services is particularly damaging for these families because these immigrant parents' jobs rarely provide benefits, like health insurance.

Immigration policies not only economically impact unauthorized immigrants and their families but also lead to long-lasting challenges in other areas of family life. Given the heavy restrictions for legal migration, for example, many immigrant families face perilous border crossings, and are likely to have spent some time apart, migrating in stages (Suárez-Orozco et al. 2002). In many cases, this is because families can only afford to send one migrant at a time. After one or both parents migrate, it may take several years for them to earn enough money to finance their children's migration (Dreby 2010). Even in cases when immigrants have legal status, the multiyear backlog on immigrant visa applications can take more than a decade to complete (Abrego 2014; Menjívar 2006). That is, even when immigrants do everything in their power to follow the laws, they may be waiting many years before they can legally reunite with their families.

The Effect of Unauthorized Status on Family Relationships

Such restrictive immigration policies and bureaucratic backlogs can also create tension and added burdens for families whose members are already structurally vulnerable. Beyond the usual family challenges of communicating and working together across generations, unauthorized immigrant parents and children may struggle to establish a family relationship after being separated and reunited years later (Suárez-Orozco et al. 2010). In one case, Mario, who came from Guatemala at age 6, still struggled 
to adapt during his teenage years. He shared the painful unresolved issues he associated with his father's migration when Mario was only a few months old:

It's not a good feeling. I mean, I knew I had a father, but, it was just, he wasn't there.... It's still not easy getting along with my dad. We disagree a lot.... I was just thinking too highly of my dad, because I never knew him, you know. Things are just not how I figured.... I've never been really attached to my dad because of that reason ... I guess he expected me to, you know, be like, 'wow, my dad' (in dreamy tone). But it was just like, how could I show that if he wasn't there? You know.

In Mario's situation, as in many others, being apart from parents over several year can lead to the development of idealized and unrealistic expectations. It is difficult to establish loving bonds and meaningful communication when parents and children have not been able to reside under the same roof, or even in the same country, for years.

As is evident in Abrego's research, even short separations can be difficult for young children. Luis, whose parents migrated from Mexico to the US during his early childhood, only spent a few months with his grandmother before his own migration at the age of four. He was separated from his father for years, but only apart from his mother for a few months. Still, as a young adult, Luis felt uneasy about his relationship with his mother:

Those 3 months made a huge difference. I didn't remember her. It felt like she wasn't my mom. You know what I mean? It felt like she was someone else. And it was only 3 months. I remember like when I used to get mad at her, if I was in trouble and she was telling me what to do, in my mind I was like, 'what if she's not my mom? What if she's another person?' ... I mean, that's your logic at that age.

These separations, particularly during formative years, can confuse children and make them question their parents' authority. As restrictive immigration policies prolong separation, long-awaited reunifications are likely to involve difficult transitions that further complicate family dynamics. Children 
often report that feelings of abandonment and resentment surface, as it is easier to blame parents for their decision to leave than to blame legal barriers, particularly when it is not clear that immigration policies and backlogs are more accurately to blame.

After families have spent many years together in the US, there are still specific hurdles that arise when one or several members are unauthorized. In particular, undocumented individuals of one generation (e.g., parents and spouses) may have distinct experiences that differ from those of the next (e.g., children), thus leading to tensions regarding how to approach their lives in the US. These intergenerational conversations must take place in a social and legal context that sets parents and children up for very different socialization experiences (Abrego 2008; 2011; Gleeson and Gonzales 2012). Families with undocumented children who grow up in the US face unique challenges.

Undocumented youth who can legally attend public school through the end of high school are socialized mainly through school, where until their late adolescence, they live much like their authorized and US citizen peers. In these cases, their experiences can lead them to develop an understanding of their legal status as a source of stigma, while their parents have a very different perspective.

Undocumented immigrant youth also face numerous challenges throughout adolescence. For example, many struggle with the shame of not being able to drive a car, date, go clubbing, or travel abroad like the rest of their peers (Gonzales 2011; Gonzales and Chavez 2012). Unlike their undocumented parents, moreover, undocumented youth have adapted to US social norms and can more easily fit in. This prompts them to participate in activities that their parents consider too risky, thereby adding tensions to family dynamics when parents disapprove of their children's behavior. The consequences of unauthorized status-being excluded from otherwise typical experiences for people their age-can be deeply frustrating for young people. 
The aspect of this dynamic that can be especially hurtful for families is that sometimes, rather than blaming the legal system that prevents them and their families from thriving, youth are tempted to blame their parents. Ultimately, in these situations, despite their parents' best efforts to provide opportunities for a better life in the US, many young people in immigrant families have a difficult time finding and taking advantage of opportunities for upward mobility.

\section{Debilitating Fear}

The most overwhelming repercussions of immigration policies for immigrant families lie in the deep-seated fear that permeates so many of their lives as a result of increased enforcement and changing policies at the federal, state, and local level. Even in the process of daily survival, for example, immigrants' families must often also grapple with changing laws and implementation practices that have the potential to devastate their economic and emotional stability. Before President Obama's administration, the Department of Homeland Security practiced enforcement most commonly through workplace raids. At the height of the raids, mothers and fathers worried daily that they might be detained in the middle of their workday.

In recent years, particularly since President Obama's first administration, the Department of Homeland Security has relied on programs such as $287(\mathrm{~g})$ and Secure Communities to increase communication between local authorities, the $\mathrm{FBI}$, and ICE agencies to ramp up immigration enforcement tactics beyond workplace raids. By deputizing local sheriffs to act as ICE agents and enabling local police to look into the legal status of all those with whom they come into contact, these enforcement practices have led to vastly increased numbers of detentions and deportations. Under current enforcement practices, DHS reports about 400,000 immigrant deportations annually since 2008. 
These record numbers of deportations, moreover, are taking place alongside a wave of xenophobic and hateful speech, and growing animosity towards Latino immigrants (Chavez 2008; Menjívar and Abrego 2012), all of which inevitably affects families' well-being, whether or not all members are unauthorized, and even when one or more individuals in the family are US citizens through birth or naturalization. The new tactics mean that even routine traffic stops or a phone call to 911 to report a crime can quickly lead to ICE's involvement and, ultimately, to the tearing apart of families.

Indeed, the wide reach of immigration enforcement practices has been unequivocally devastating for families. The fear that these practices generate informs many aspects of immigrants' and their families' lives. For example, outside of formal channels for assistance, it can be very difficult to establish social networks when seeking aid. Not knowing with whom they can trust their secret, the fear of potential detention makes many unauthorized families worry about their everyday interactions with strangers and likely prevents greater communication within their communities. In this process, it is easy to develop feelings of exclusion that in some cases can also put these families at risk of being targets of crime (Abrego forthcoming 2014). As Norma, a Mexican first generation undocumented immigrant mother in Los Angeles, sums it up, “we are here and we know this is not our country. They don't want us here, so you have to be careful. Always be careful." Because of the current level of immigration enforcement, immigrants are made to feel constantly insecure, unsure of who they can trust, and unable to rely even on institutions that should represent safety for all.

How US Citizens Also Suffer

Beside the 500,000 undocumented children in the US growing up in families with at least one undocumented parent (Taylor et al. 2011), an additional 4.5 million US citizen children are growing up in 
mixed status families in which at least one of their parents is undocumented (Taylor et al. 2011). Significantly, for reasons of border militarization and restricted paths to legalization, the latter figure more than doubled between 2000 and 2011. This means that US-born citizens are not entirely protected from the consequences of anti-immigrant laws-particularly when their loved ones are undocumented. By 2011, among the record number of deportees, a full $22 \%$ of undocumented parents who faced deportation were parents of US citizen children (Wessler 2011).

Mixed status families not only share many of the same challenges and experiences as undocumented families, but also face unique tensions and challenges as a result of the different legal statuses of their members. Immigration policies can play out in numerous ways, partly depending on the role of the undocumented persons and their relationships relative to others. For example, unauthorized status will have different repercussions in a family that includes an unauthorized parent and US citizen children versus a family that includes a US citizen parent and children with various statuses.

Today, with heightened criminalization of immigrants and record numbers of deportation, many families experience associated stress and fear. Indeed, this level of seemingly random and punitive enforcement spreads insecurity through entire families, whether or not all members are unauthorized. This is evident in the narratives of children of immigrants who grew up with one or two undocumented parents. Even in Southern California, a region generally known to be welcoming to immigrants, young adults report growing up with great fear. For example, 22-year-old Mayra was born in the US; as a US citizen, immigration policies should not pertain to her. Yet, the topic made her nervous; her mother is an unauthorized immigrant from Guatemala. As she explained:

Talking about my mom is hard. It's like there's this whole cloud of, like, a whole heaviness (motions as though she is carrying weight on her shoulders and above her head), I don't know, of things that I was never allowed to say out loud. If she was ever 
late, if she wasn't back from church or from work right on time, we all worried... Nobody said anything, but we were all thinking it: what if she got caught? ... That weight, it's just fear, I guess ... it really sucks to grow up like that.

Experiences like Mayra's are proof of the anguish that citizen children experience as a result of current implementation of US immigration policies. Even though she was born a US citizen, the fear of detention and deportation — some of the gravest repercussions of immigration policies-also affected her throughout her life and in very powerful ways.

These fears are certainly validated by immigration enforcement statistics. Those immigrants who are detained and deported are now likely to include members of mixed status families-particularly the parents of US citizen children. When parents are deported, children are often then placed in foster care with little regard for the principle of family unity that presumably guides both immigration and child welfare policies (Wessler 2011). Such was the case of Encarnación Bail Romero, a Guatemalan immigrant to the US (Brané 2011; Thompson 2009). In 2007, while working at a poultry plant in Missouri, immigration officials detained Bail Romero in a workplace raid. Her son, Carlos, who was then only 6 months old, spent some time with different caretakers, until a couple approached her about adopting him. She was adamantly against this option, but helpless from within a detention center in another state. Her lawyer, who only explained the situation to her in English (a language she did not understand), failed to protect her. Unable to leave detention, she later learned that a judge used her absence in court for a hearing about Carlos' future as evidence of abandonment. In response, the judge terminated her parental rights, and another family legally adopted Carlos, who was a US citizen by birth.

Although Ms. Bail had been trying to regain custody of her son for more than 5 years, immigration laws stood against her and she finally and irreparably lost custody in 2012. Scores of deported immigrant parents have faced similar charges of deserting their children, risking losing them to 
the foster care system, and ultimately had to face the painful prospect of never seeing them again. Other research has also extensively documented the challenges facing US citizen children whose only chance for family unity required their departure from the US (Dreby 2012; Passel et al. 2012). These cases, while extraordinary, reflect an increasingly common experience in the current historical moment: The legal system denies undocumented immigrants the same parental rights that are guaranteed to other parents-even when US family laws would otherwise aim to keep parents and children together. Understandably, knowledge of cases like these instills great fear in immigrants.

The deeply divisive and largely misinformed US national debate about undocumented immigrants and immigration laws often masks the broad repercussions of ramped up enforcement for immigrant families. Such harshly restrictive immigration policies are harming individuals and their entire families, whether or not all of the members are unauthorized (Menjívar and Abrego 2012). Thousands of families experience anguish resulting from the current implementation of US immigration policies. Even US citizens, either by birth or through naturalization, live with the fear that their closest family and friends will face detention and deportation-possibly the gravest repercussions associated with undocumented status. Even though they are not the targets of this legal enforcement, entire families have to negotiate these repercussions and face a heavy added burden shaping all of their members. These experiences, moreover, have long-term consequences for family communication, relationships, and well-being.

All of the repercussions associated with immigration enforcement also directly undermine families' efforts to move out of poverty. Like parents in other working poor families, undocumented parents often work in low-paying, unstable jobs, with few to no benefits for long periods of time. And, like other children who grow up in poverty, (documented and undocumented) children of undocumented immigrants also face high levels of danger, few educational opportunities, frequently 
lack health insurance (Fortuny et al. 2007), and have limited access to bank accounts and other financial services. Due to fear of deportation, undocumented parents also often avoid applying for those benefits they or their children may be eligible for, such as food stamps and Medicaid (Abrego and Menjívar 2011).

\section{Undocumented Status and Family Separation}

Immigrants and their families may also experience the harsh consequences of immigration policies that can prevent them from reuniting across borders over several years. Long-term separation of members of transnational families, in which core family members live across borders, is not uncommon among Mexican, Central American, and other Latin American immigrants. In these cases, unable to survive in their countries of origin, parents opt to migrate to the US in search of work to support their children from afar. The vast wage inequalities in the region make this a likely strategy.

Importantly, US foreign policies play an enormous role in pushing people out of their home countries in the first place, although immigration debates typically fail to recognize this. This is true for many sending countries, and especially evident in Central America where massive migration to the US began only after prolonged US funding of wars in the region in the 1970s and 1980s. Today, vast economic inequalities continue to be reinforced and exacerbated through the consequences of the North American Free Trade Agreement (NAFTA) and the Dominican Republic- Central American Free Trade Agreement (CAFTA-DR) that have benefited elites while constricting the masses. Unable to survive on the measly salaries in limited job opportunities that have become the norm since the implementation of these free trade agreements, people feel forced to migrate as their only option. Once they arrive in 
the US, however, immigration laws restrict their chances for family reunification, making for prolonged family separations-often at least a decade (Abrego 2009).

It is difficult to enumerate how many people live in these types of arrangements, but it is a notable proportion of families from various countries throughout Latin America (Abrego 2009; Dreby 2010; Hondagneu-Sotelo and Avila 1997; Pribilsky 2004; Schmalzbauer 2005). In El Salvador, for example, it is estimated that anywhere between 16 and $40 \%$ of children in various regions of the country are growing up without one or both parents due to migration (García 2012; Martínez 2006). For these families, US immigration policies are likely to play out differently than for families that are forced apart through deportation or who live together in fear.

Transnational families may be constituted in a number of different ways. Here, we focus on families in which parents migrated to support their children who remain in the home country. In these cases, female relatives-mothers, grandmothers, aunts, or older sisters - typically stay behind to care for children. Parents work in the US to send remittances to families who often rely solely on these monies to survive. Each member of the family, then, experiences illegality differently. Unauthorized migrant parents feel the brunt of the criminalization and exclusion associated with unauthorized status from the moment they leave their home. Once in the US, unable to reach their financial goals, even when they work multiple jobs and overtime, immigrant parents experience illegality as frustration towards stalled economic mobility and fear of deportation.

Meanwhile, back in their home countries, caregivers and children suffer the migrants' absence and lack of resources due to undocumented status. When migrants are separated from their families for years, their relatives must also grapple with the consequences of US immigration policies. Much of the tension for transnational families who rely on undocumented or only temporarily protected family members comes from the limited sums of remittances, which may be a result of being employed in 
sectors that are dangerous and exploitative (Holmes 2007; Milkman et al. 2010; Walter et al. 2004). For transnational families, these limited remittances provide little support to improve material circumstances in their lives. The results often include continued poverty and increased tension when mothers and fathers cannot live up to their parental expectations. Because separation was supposed to lead to financial stability, children in transnational families can become hurt, confused, and resentful. The severity of suffering stems from a sense of abandonment that many children feel because there is little to show for the family sacrifice of separation (Abrego 2014).

\section{Conclusion}

Despite the common assumption that immigration laws target only undocumented immigrants, they in fact intimately and deeply impact a larger proportion of immigrants and particularly Latinos. These policies contextualize immigrants' ability to integrate and be upwardly mobile, and shape their long-term relationships both in the US and abroad. They impact family dynamics as well-forcing parents and children to live across borders over a prolonged period; multiplying families' vulnerability when they are all undocumented residing together; or complicating family relationships when only one or a few members are in tenuous statuses but they reside with others who have more rights and protections. Fear of deportation limits parents' authority while adding responsibilities for parents and children (Abrego and Menjívar 2011). Consequently, children have to carry part of the burdensometimes financially, often emotionally - to help the family survive despite the limitations. Immigration policies, moreover, prevent all parents from accessing social services and other resources to help their children achieve optimal well-being.

In the long term, undocumented status keeps families in the shadows, avoiding many of the very institutions that have traditionally benefited immigrant families (Menjívar 2006). In these cases, immigrants and their families experience immigration policies as extreme vulnerability that can 
penetrate even their most intimate relationships. Moreover, the disenfranchisement of undocumented immigrants from the formal political realm excludes their voice from important policy discussions and leads to political underrepresentation (Montforte and Dufour 2011). This makes immigrants and their families vulnerable, as they must rely on others to represent their interests in policy making.

\section{Policy Recommendations}

In many respects, unauthorized immigrants and their families are already important members of US society-even if only on the lower rungs of the economic ladder. They contribute to our economy, their children are educated in our schools, and all family members envision their futures here. However, these families currently have no available structural paths out of poverty. In a cruel twist, parents' efforts to secure their families' survival by migrating are met with legal obstacles. Current policies restrict their ability to thrive in this country and, for transnational families, to pull children out of poverty in the home countries as well. Without full legal rights, these families are barred from the very mechanisms that have ensured high levels of economic and social mobility to other immigrants throughout US history (Abrego 2006; Menjívar and Abrego 2012). A complete path to citizenship, therefore, is necessary to give Latino families a chance at success in this country. Entry policies should also be reassessed to address the reality of a globalizing world and economy.

Short of legalization, there are several significant changes in policy that would improve immigrant families' chances of thriving. Currently, thousands of children of deported parents are being separated from their families and placed into the foster care system without prior notice. To prevent the trauma that likely ensues for these families, Congress should pass legislation to ensure that children are not unnecessarily separated from their families and mandate minimum standards for immigration 
enforcement when children are involved. Policies should ensure that parents are able to continue making decisions about their family's well-being and take the interests of the children into account in enforcement decisions. Discretion is particularly necessary for the current flood of unaccompanied minors who are being deported from the southern US border.

Insert Figure 1 Here

Another small but significant change in policy could greatly improve the situation of many families. Currently, immigrant family members who are adjusting to legal status are subject to the provisions of immigration law that bar undocumented immigrants from reentering the US for 3 or 10 years (depending on how long they were in the country without status). In other words, even when they are married to a US citizen, or have US citizen children, immigrant relatives are required to leave the country for 3-10 years to adjust this status. This is a huge burden on families. Instead, the government should allow these family members to remain in the US while they apply for a waiver of the bar (known as a waiver of inadmissibility).

All families rely on workers for economic survival. To protect immigrant families, therefore, policies that target the improvement of the workplace are also required. Given the continuing attacks on immigrant workers' rights and the increased possibility of exploitation in various industries, the government should ensure that all people in the US, regardless of status, have strong worker protections, and should prosecute employers that exploit immigrant workers. Solutions to legal violence in the workplace should ensure "that workers know their rights, have full status under the law to assert them, have access to sufficient legal resources, and do not fear retaliation" (Milkman et al. 2009, p. 6). 
When workers are paid fair wages and when their rights are upheld, it is more likely that immigrant families will also thrive (Fig. 1). 


\section{References}

Abrego LJ (2006) ‘I Can't Go to College Because I Don't Have Papers': incorporation patterns of Latino undocumented youth. Lat Stud 4:212-231

Abrego $L$ (2008) Legitimacy, social identity, and the mobilization of law: the effects of assembly bill 540 on undocumented students in California. Law Soc Inq 33:709-734

Abrego LJ (2009) Economic well-being in Salvadoran transnational families: how gender affects remittance practices. J Marriage Family 71:1070-1085

Abrego LJ (2011) Legal consciousness of undocumented Latinos: fear and stigma as barriers to claims making for first and 1.5 generation immigrants. Law Soc Rev 45:337-370

Abrego LJ (2014) Sacrificing families: Navigating laws labor and love across borders. Stanford University Press, Stanford

Abrego LJ, Menjívar C (2011) Immigrant Latina mothers as targets of legal violence. Int J Sociol Family $37: 9-26$

Abrego LJ, Gonzales R (2010) Blocked paths, uncertain. Futures the postsecondary education and labor market prospects of undocumented Latino youth. J Educ Stud Placed Risk (JESPAR) 15:144-157

Avendaño A, Hincapié M (2008) The rollback of immigrant workers' civil rights. Point of View. AFL-CIO. http://www.aflcio.org/mediacenter/speakout/aa_mh.cfm. Accessed 23 June 2014

Berman JS (2004) The needle and the damage done: how Hoffman Plastics promotes sweatshops and illegal immigration and what to do about it. Bepress Legal Series

Bernhardt A, Milkman R, Theodore N, Heckathorn D, Auer M, DeFilippis J, González AL et al (2009) Broken laws, unprotected workers: violations of employment and labor laws in America's cities. 
Center for Urban Economic Development, Chicago. (National Employment Law Project, New York. UCLA Institute for Research on Labor and Employment, Los Angeles). http://nelp.3cdn.net/319982941a5496c741_9qm6b92kg.pdf. Accessed 23 June 2014

Brané M (2011) Delayed justice for Guatemalan mother Encarnación Bail Romero. Huffington Post, February 5. http://www.huffingtonpost.com/michelle-bran/delayed-justice-forguate_b_817191.html. Accessed 23 June 2014

Burnham L, Theodore N (2012) Home economics: the invisible and unregulated world of domestic work. National Domestic Workers Alliance Center for Urban Economic Development, University of Illinois at Chicago DataCenter, New York. http://www.domesticworkers.org/homeeconomics/. Accessed 23 June 2014

Calavita K (1992) Inside the state: the Bracero program, immigration, and the INS. Routledge, New York Calderon-Barrera DA (2003) Hoffman V. NLRB: leaving undocumented workers unprotected under United States Labor Laws? Harv Lat Law Rev 6:119-143

Chavez LR (1998) Shadowed lives: undocumented immigrants in American society. Harcourt Brace, Fort Worth

Chavez LR (2008) The Latino threat: constructing immigrants, citizens, and the nation. Stanford University Press, Palo Alto

Dreby J (2010) Divided by borders: Mexican migrants and their children. University of California Press, Berkeley

Dreby J (2012) How today's immigration enforcement policies impact children, families, and communities: a view from the ground. Center for American Progress, Washington, DC. 
http://www.americanprogress.org/wp-

content/uploads/2012/08/DrebylmmigrationFamiliesFINAL.pdf. Accessed 23 June 2014

DHS, Department of Homeland Security (2008) Detailed methodology for annual estimates of the unauthorized immigrant population residing in the United States: 1990-2000. Office of Immigration Statistics, Washington, DC.

www.dhs.gov/xlibrary/assets/statistics/publications/III_Report_1211.pdf. Accessed 23 June 2014

DOL, Department of Labor (2007) 2003 statistics fact sheet: wage and hour fiscal year 2003 enforcement continues record climb. Statistics. November 14. US Department of Labor, Washington, DC. http://www.dol.gov/whd/statistics/200318.htm. Accessed 23 June 2014

Fisk C, Cooper L, Wishnie MJ (2005) The story of Hoffman Plastic Compounds, Inc. V. NLRB:

labor rights without remedies for undocumented immigrants. Duke Law School Faculty Scholarship Series, Paper 20. http://scholarship.law.duke.edu/faculty_scholarship/1243. Accessed 23 June 2014

Foo $L J$ (1994) The vulnerable and exploitable immigrant workforce and the need for strengthening worker protective legislation. Yale Law J 103(8):2179-2212

Fortuny K, Capps R, Passel J (2007) The characteristics of unauthorized immigrants in California, Los Angeles county, and the United States. The Urban Institute, Washington, DC

García JJ (2012) 20th anniversary of El Salvador's peace accords and implications for transnational development and voting abroad. In UCLA North American Integration and Development Center. Los Angeles, CA 
Gleeson S (2010) Labor rights for all? The role of undocumented immigrant status for worker claims -making. Law Soc Inq 35(3):561-602

Gleeson S (2013) 2013 Rights in theory, rights in practice: unpacking the individual and institutional elements of enforcing worker rights. Labor and labor movements mini-conference: labor and global solidarity, American Sociological Association annual meeting, New York,NY 8/12/13

Gleeson S, Gonzales RG (2012) When do papers matter? An institutional analysis of undocumented life in the United States. Int Mig 50(4):1-19

Gonzales R (2011) Learning to be illegal: undocumented youth and shifting legal contexts in the transition to adulthood. Am Sociol Rev 76:602-619.

Gonzales RG, Chavez LR (2012) Awakening to a nightmare: abjectivity and illegality in the lives of undocumented 1.5 generation Latino immigrants in the United States. Curr Anthropol 53:255281.

Hoefer M, Rytina N, Baker B (2011) Estimates of the unauthorized immigrant population residing in the United States: January 2011. DHS Office of Immigration Statistics, Washington, DC. http://173.201.144.90/attachments/2642_ois_ill_pe_2011.pdf. Accessed 23 June 2014

Holmes SM (2007) Oaxacans like to work bent over: the naturalization of social suffering among berry farm workers. Int Migr 45:39-68

Hondagneu-Sotelo P (1994) Gendered transitions: Mexican experiences of immigration. University of California Press, Berkeley

Hondagneu-Sotelo P, Avila E (1997) 'I'm here, but I'm there': the meanings of Latina transnational motherhood. Gend Soc 11:548-570 
International Organisation for Migration (2008) Global estimates and trends. Geneva, Switzerland. http://www.iom.int/cms/en/sites/iom/home/about-migration/facts-figures-1/globalestimatesand- trends.html. Accessed 23 June 2014.

Loh K, Richardson S (2004) Foreign-born workers: trends in fatal occupational injuries, 1996-2001. Mon Labor Rev June:42-53

Martínez L (2006) El rostro joven de las remesas. In El Diario de Hoy. San Salvador, El Salvador Menjívar C (2006) Family reorganization in a context of legal uncertainty: Guatemalan and Salvadoran immigrants in the United States. Int J Sociol Family 32:223-245

Menjívar C, Abrego L (2012) Legal violence: immigration law and the lives of Central American immigrants. Am J Sociol 117:1380-1424

Milkman R, González AL, Narro V (2010) Wage theft and workplace violations in Los Angeles: the failure of employment and labor law for low-wage workers. UCLA Institute for Research on Labor and Employment, Los Angeles.

Motomura H (2010) The rights of others: legal claims and immigration outside the law. Duke Law J 59:1723-1786

NELP and MALDEF (2003) Used and abused: the treatment of undocumented victims of labor law violations since Hoffman Plastic Compounds V. NLRB. National Employment Law Project and Mexican American Legal Defense and Education Fund, New York.

Nissen B, Angee A, Weinstein M (2008) Immigrant construction workers and health and safety: the South Florida experience. Labor Stud J 33(1):48 
NLRB, National Labor Relations Board (2011) Board holds that supreme court decision forecloses backpay remedy for undocumented immigrant workers. National Labor Relations Board, Washington, DC. http://www.nlrb.gov/. Accessed 23 June 2014.

Morgan DC, Godsil RD, Moses J (2006) Awakening from the dream. Carolina Academic Press, Durham.

Monforte P, Pascale D (2011) Mobilizing in borderline citizenship regimes: A comparative analysis of undocumented migrants' collective actions. Politics \& Society 39(2):203-232

Passel J, Cohn D’Vera (2009) A portrait of the unauthorized migrants in the United States. Pew Hispanic Center, Washington, DC. http://pewhispanic.org/files/reports/107.pdf. Accessed 23 June 2014

Passel J, Cohn D’Vera (2011) Unauthorized immigrant population: national and state trends, 2010.

Pew Hispanic Center, Washington, DC. http://www.pewhispanic.org/2011/02/01/unauthorizedimmigrant-population-brnational-and-state-trends-2010/. Accessed 23 June 2014

Passel J, D’Vera C (2012) Unauthorized immigrants: 11.1 Million in 2011. Washington D.C. http://www.pewhispanic.org/2012/12/06/unauthorized-immigrants-11-1-million-in-2011/

Passel J, Cohn D’Vera, Gonzalez-Barrera A (2012) Net migration from Mexico falls to zero-and perhaps less. Washington, DC http://www.pewhispanic.org/files/2012/04/Mexicanmigrantsreport_final.pdf. Accessed 23 June 2014

Pribilsky J (2004) 'Aprendemos a convivir': Conjugal relations, co-parenting, and family life among Ecuadorian transnational migrants in New York City and the Ecuadorian Andes. Glob Netw 4:313-334

Salcido O, Cecilia M (2012) Gendered paths to legal citizenship: The case of Latin-American immigrants in Phoenix, Arizona. Law \& Society Review 46(2):335-368 
Schmalzbauer L (2005) Striving and surviving: a daily life analysis of Honduran transnational families. Routledge, New York

Simmelink J (2011) Temporary citizens: US immigration law and Liberian refugees. J Immigr Refugee Stud 9(4):327-344

Suárez-Orozco C, Todorova I, Louie J (2002) Making up for lost time: the experience of separation and reunification among immigrant families. Fam Process 41:625-643

Suárez-Orozco C, Bang HJ, Kim HY (2010) I felt like my heart was staying behind: psychological implications of family separations and reunifications for immigrant youth. J Adolesc Res 20:1-36

Taylor P, Lopez MH, Passel J, Motel S (2011) Unauthorized immigrants: length of residency, patterns of parenthood. Pew Hispanic Center, Washington, DC

The White House (2011) Remarks by the president on comprehensive immigration reform in El Paso, Texas. http://www.whitehouse.gov/the-press-office/2011/05/10/remarks-presidentcomprehensive- immigration-reform-el-paso-texas. Accessed 23 June 2014

Thompson G (2009) After losing freedom, some immigrants face loss of custody of their children. New York Times, April 22. http://www.nytimes.com/2009/04/23/us/23children.html?pagewanted=all\&_r=0. Accessed 23 June 2014

Thronson DB (2008) Creating crisis: immigration raids and the destabilization of immigrant families. Wake For Law Rev 43:391

Valenzuela A Jr, Theodore N, Melendez E, Gonzalez AL (2006) On the corner: day labor in the United States. UCLA Center for the Study of Urban Poverty, Los Angeles 
Walsh TJ (2003) Hoffman Plastic Compounds, Inc. V. NLRB: how the Supreme Court eroded labor law and workers in the name of immigration policy. Law Inequal 21:313

Walter N, Bourgois P, Loinaz HM (2004) Masculinity and undocumented labor migration: injured Latino day laborers in San Francisco. Soc Sci Med 59:1159-1168

Wasem RE (2012) Unauthorized aliens residing in the United States: estimates since 1986. Congressional Research Service, Washington, DC. http://www.fas.org/sgp/crs/misc/RL33874.pdf. Accessed 23 June 2014

Wessler SF (2011) Shattered families: the perilous intersection of immigration enforcement and the child welfare system. Applied Research Center, New York

Wessler SF (2012) Primary data: deportations of parents of US citizen kids (Deportations of Parents of US-Born Citizens, July 1, 2010-Sept 31, 2012). New York and Oakland: Colorlines: News for Action.

http://colorlines.com/archives/2012/12/deportations_of_parents_of_usborn_citizens_122012. html. Accessed 23 June 2014

Wishnie MJ (2007) Prohibiting the employment of unauthorized immigrants: the experiment fails. Univ Chic Leg Forum 2007:193-217

Zahniser S, Hertz T, Dixon P, Rimmer M (2012) Immigration policy and its possible effects on US agriculture and the market for hired farm labor: a simulation analysis. Am J Agrc Econ $94(2): 477-482$ 


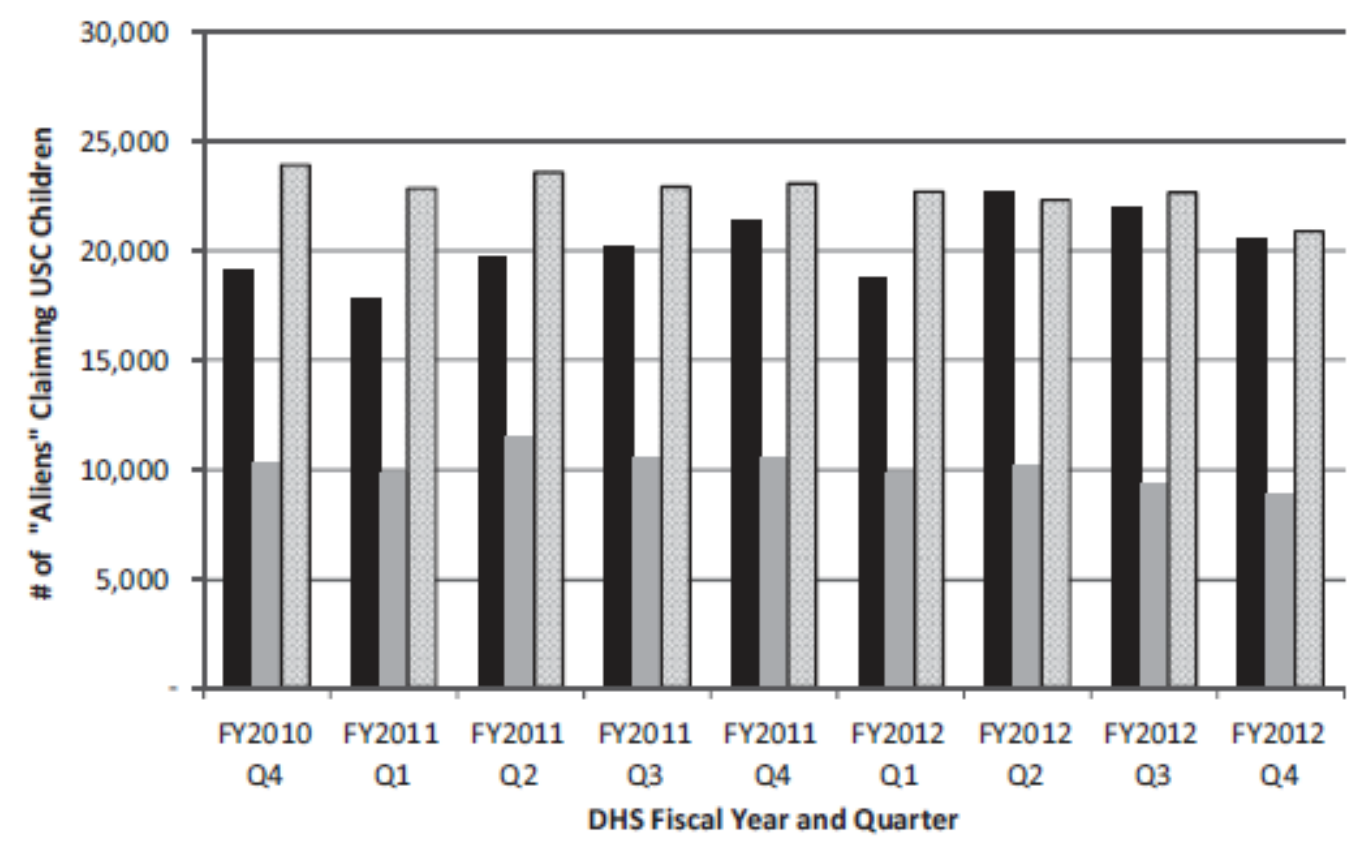

- Final Orders Sought Final Orders Obtained $\square$ Number of Removals

Fig. 1 Removal proceedings for "Aliens" claiming US citizen children. (Source: Freedom of Information Act Request to the Department of Homeland Security by the Colorlines.com and the Applied Research Center (Wessler 2012). Available at: http://colorlines.com/archives/2012/12/ deportations_of_parents_of_us-born_citizens_122012.html) 